Arq. Bras. Med. Vet. Zootec., v.71, n.3, p.909-916, 2019

\title{
Effects of exercise on cations/anions in blood serum of English Thoroughbred horses
}

[Efeito do exercício sobre cátions/ânions em soro sanguíneo de equinos da raça Puro-Sangue-Inglês]

R.O.F. Prado h.O.F. Prado
B.J.E. Morcid.org/0000-0001-8802-0177 https://orcid.org/0000-0001-9344-1873 R.O.F. Prado ${ }^{1}$, B.J.E. Morales ${ }^{2}$, M.L.J. García ${ }^{3}$, J. Molina-Ochoa ${ }^{1,3}$, S.G. Valpuesta ${ }^{1}$, R.J.A. Hernández ${ }^{1}$, C.A.C. García ${ }^{1}$

${ }^{1}$ Universidade de Colima - Tecomán Colima, México

${ }^{2}$ Universidade Autónoma Metropolitana - Cidade do México, México ${ }^{3}$ Centro Universitario de Investigação e Desenvolvimento Agropecuário - Tecomán Colima, México

M.L.J. García
https://orcid.org/0000-0001-7066-4660 J. Molina-Ochoa https://orcid.org/0000-0002-8006-301 S.G. Valpuesta https://orcid.org/0000-0002-8081-455 R.J.A. Hernánde https://orcid.org/0000-0003-1805-5264 https://orcid.org/0000-0002-7716-210X
Paría

\begin{abstract}
English Thoroughbred horses, are widespread in Mexico and due to the lack of data on their exercise physiology, it is important to conduct exercise tests in order to obtain information the effects of exercise on more essential cations/anions in blood serum, as these horses are submitted to constant efforts. The study was carried out with 150 blood samples of English Thoroughbred horses clinically healthy. The blood sample collection was performed during three periods: 1) rest, 2) 30min after exercise (speed race of $12 \mathrm{~km} / \mathrm{h}$ for $30 \mathrm{~min}$ with no rest) and 3) 60min after exercise. Mean values were calculated for cations (sodium and potassium) and anions (chloride and bicarbonate). The resulting data set was analyzed using Gaussian distribution and descriptive statistics. Confidence intervals of $95 \%$ were established. The linear relationships between ions were quantified, and an analysis of variance was performed to compare the mean values between groups. The concentrations of the described analytes are consistent with values reported by international literature. The comparison between groups, revealed that during exercise, sodium ion did not show changes 30min after exercise and increase $60 \mathrm{~min}$ after. Potassium ion showed increase $30 \mathrm{~min}$ after exercise and decrease $60 \mathrm{~min}$ after. Chloride ion showed a decrease 30min after exercise, to recover gradually 60min after. Meanwhile, bicarbonate ion showed increase $30 \mathrm{~min}$ after exercise, decreasing slightly in the final stage. Negative correlation between bicarbonate ion and chloride ion were determined. It was concluded that exercise tests are useful for the determination of acid-base balance and osmotic balance, and their main role is to evaluate the athletic ability of horses.Considering that chloride ion excretion and metabolic adjustments of potassium ion and bicarbonate ion are superior to water loss, compared to the normal osmolarity of blood serum. The results found can be used to structure an adequate replacement program of electrolytes lost in sweat.
\end{abstract}

Keywords: english thoroughbred horses, blood chemistry, metabolic profile, osmotic balance

\section{RESUMO}

Equinos da raça Puro-Sangue-Inglês são difundidos no México e, devido à falta de dados sobre sua fisiologia do exercício, é importante fazer testes de exercício para obter informações sobre os efeitos do exercício em cátions/ânions mais essenciais no soro do sangue, pois esses equinos são submetidos a esforços constantes. $O$ estudo foi realizado com 150 amostras de sangue de equinos Puro-Sangue-Inglês, clinicamente saudáveis. A coleta de sangue foi realizada em três períodos: 1) descanso, 2) 30min após o exercício (corrida de velocidade de $12 \mathrm{~km} / \mathrm{h}$ por $30 \mathrm{~min}$, sem descanso) e 3) 60min após o exercício. Os valores médios foram calculados para cátions (sódio e potássio) e ânions (cloreto e bicarbonato). O conjunto de dados resultante foi analisado utilizando-se distribuição gaussiana e estatística descritiva. Intervalos de confiança de $95 \%$ foram estabelecidos. As relações lineares entre os íons foram quantificadas, e uma análise de variância foi realizada para se compararem os valores médios entre grupos. As concentrações dos analitos descritos são consistentes com os valores relatados na literatura internacional. A comparação entre os grupos revelou que, durante o exercício, o sódio íon não mostrou alterações 30min após o exercício e aumentou 60min após. O potássio íon mostrou aumento 30min após o exercício e diminuiu 60min após. O cloreto íon mostrou uma diminuição $30 \mathrm{~min}$ após o exercício, para recuperar gradualmente 60min depois. O bicarbonato íon mostrou aumento 30min após o exercício, diminuindo ligeiramente no estágio final. Correlação negativa entre bicarbonato íon e cloreto íon

Recebido em 20 de maio de 2018

Aceito em 25 de setembro de 2018

E-mail: cesargarciacasillas@hotmail.com 
foi encontrada. Concluiu-se que os testes de exercício são úteis para a determinação do equilíbrio ácido-base e do equilíbrio osmótico, e seu principal papel é avaliar a capacidade atlética dos equinos. Considerando-se que a excreção de cloro íon e ajustes metabólicos de potássio íon e bicarbonato íon são superiores à perda de água, comparada à osmolaridade normal do soro sanguíneo,os resultados encontrados podem ser usados para estruturar um programa adequado de reposição de eletrólitos perdidos no suor.

\section{Palavras-chave: equinos Puro-Sangue-Inglês, bioquímica sanguínea, perfil metabólico, equilíbrio osmótico}

\section{INTRODUCTION}

The sport of racing is the most demanding of equine athletic disciplines, with horses required to complete distances of up to $160 \mathrm{~km} / \mathrm{d}$ (Randle and Waran, 2017). In these activities, animals with highly developed metabolic responses are required (Doherty et al., 2017).Because the evaporation of sweat is the major mechanism for the removal of excess heat produced during exercise, there is a substantial loss of body water and electrolytes, especially cations: sodium $\left(\mathrm{Na}^{+}\right)$and potassium $\left(\mathbf{K}^{+}\right)$and anions chloride $\left(\mathbf{C l}^{-}\right)$and bicarbonate $\left(\mathbf{H C O}_{3}{ }^{-}\right)$(Potts et al., 2015; Randle and Waran, 2017). Additionally, dehydration and electrolyte imbalances increase the risk for metabolic disease, including synchronous diaphragmatic flutter (Nagy et al., 2017), and rhabdomyolysis (Wilberger et al., 2015).

Cations and anions losses during speed race, reflect a balance among sweat loss, plus water, influence of exercise intensity and duration, and index of the horse's adaptation to speed and endurance (Sanin et al., 2015).These ions are electrically charged particles, and not just inert accumulations of salt suspended in an aqueous medium (Martins et al., 2014).They are indispensable biochemical analytes in the acidbase balance of blood, the water balance of body, maintaining osmotic pressure, movement of electrical impulses and muscle contraction and relaxation (Soetan et al., 2010; Terker et al., 2015; Kataoka, 2017).For this reason, the present study determined the effect of physical exercise on the serum concentration of $\mathrm{Na}^{+}, \mathrm{K}^{+}, \mathrm{Cl}^{-}$and $\mathrm{HCO}_{3}{ }^{-}$ions in English Thoroughbred horses for its application in sports medicine.

\section{MATERIALS AND METHODS}

All animals in this study were kept following the guidelines of the (Olfert et al., 1993).
Evaluations were carried in the equestrian club Sayavedra in the Mexico City (latitude 19 25'42" $\mathrm{N}$, longitude 99 07'39" O and altitude 2240m). The mean temperature during the exercise and relative humidity were $22^{\circ} \mathrm{C}$, and $41 \%$, respectively.

Fifty English Thoroughbred horses clinically healthy, (25 stallions and 25 mares), ranging from 2 to 3 years of age and weight $400 \pm 50 \mathrm{~kg}$, were included in the study. All the horses had been trained regularly for at least one year. Blood samples were collected, between 8:00 and 11:00 a.m., by puncture of the jugular vein during three periods: 1) rest, 2) 30min after exercise (speed race of $12 \mathrm{~km} / \mathrm{h}$ for $30 \mathrm{~min}$ with no rest) and 3) 60min after exercise, using $8.5 \mathrm{~mL}$ vacuum tubes with clot activator and serum separator gel (BD Vacutainer 367988; BectonDickinson Co., Franklin Lakes, United States). The serum was separated by centrifuging directly at the equestrian club at $1500 \times \mathrm{g}$ for $10 \mathrm{~min}$ using a portable centrifuge (Porta-Spin C828; UNICO., Dayton, United States). Subsequently, the serum samples were separated using $1.5 \mathrm{~mL}$ tubes with lid (Tubes Safe-Lock 3810X; Eppendorf., Madrid, Spain) and transported at $4^{\circ} \mathrm{C}$ in a portable cooler (Thermoelectric Cooler Car/Home M5644-710; Coleman Company., Kansas, United States) to the clinical laboratory of the Universidad Autónoma Metropolitana campus Xochimilco, where they were frozen at $20^{\circ} \mathrm{C}$ (Biomedical Freezer MDF-U5412H-PE; PHC Europe B.V., Amsterdam, Netherlands) until analysis.

The concentration of $\mathrm{Na}^{+}, \mathrm{K}^{+}, \mathrm{Cl}^{-}$and $\mathrm{HCO}_{3}^{-}$ ions was determined with an UV/Vis spectrophotometer (Biochemistry Analyzer ES218; KONTROLab., Guidonia, Italy). Table 1 describes measured biochemical analytes, the analytical method employed to obtain each parameter, and the corresponding commercial reagents used. 
Table 1. Biochemical analytes, units, analytical methods, and corresponding commercial reagents

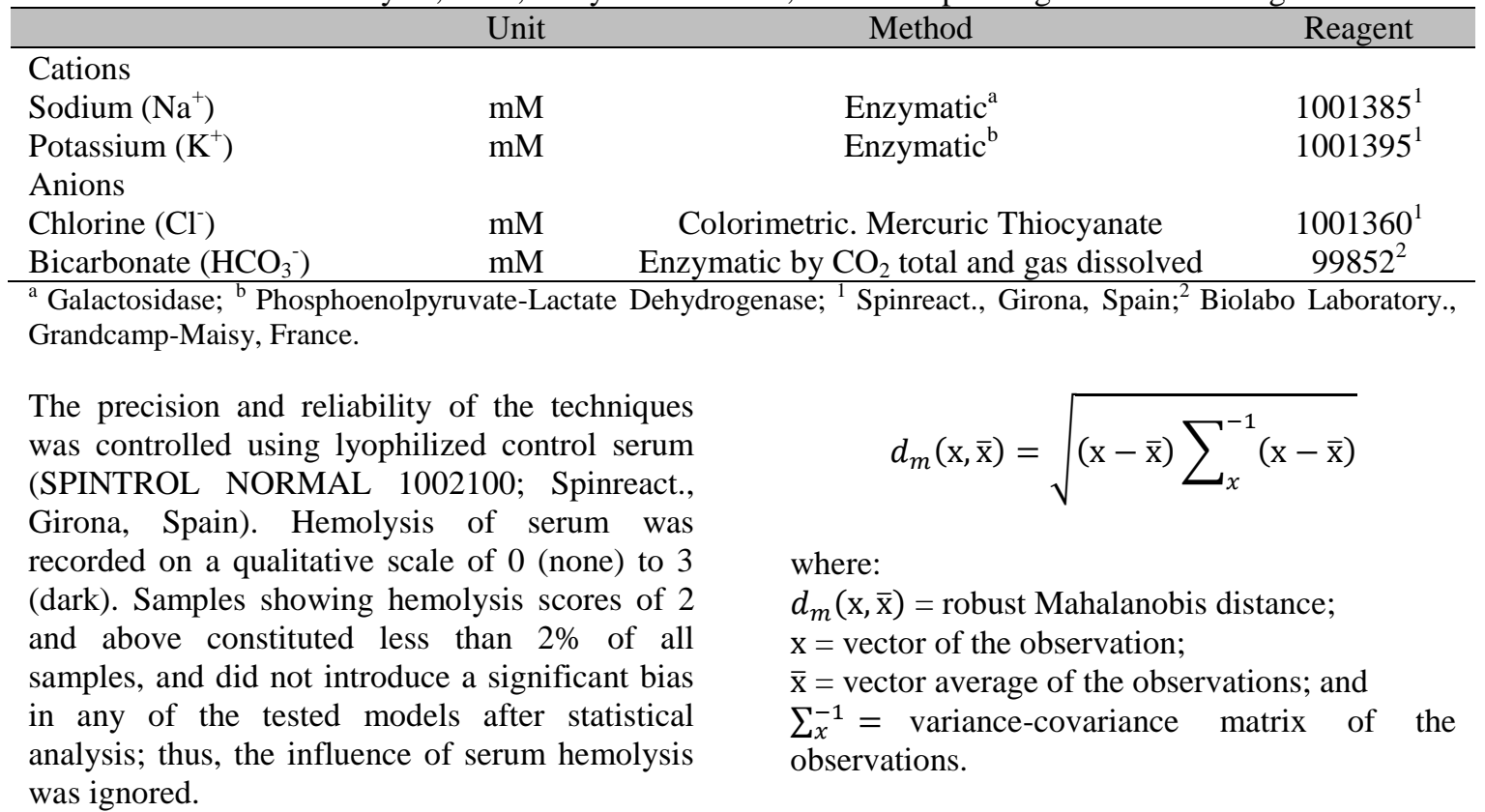

Data were analyzed using Gaussian distribution, and percentiles: $\mathrm{P}_{10}-\mathrm{P}_{90}, \mathrm{P}_{25}-\mathrm{P}_{75}$ were determined by SPSS Univariate Procedure (SPSS..., 2013). The comparison between groups: 1) rest, 2) 30min after exercise and 3) 60min after exercise, was assessed by Analysis of Variance. A multiple comparison test of Tukey was performed when the effect of group was found to be significant $(\mathrm{P}<0.05)$. The linear relationships betweenbiochemical analytes were identified by the use a Pearson Correlation Coefficient matrix.A diagnosis for outlier values was performed using robust multivariate outlier detection. This macro calculates the robust Mahalanobis distance for each observation. The following model was tested:
A diagnosis for models main asssumptions was performed. Linear functional form was visually checked by a normal plot. Shapiro-Wilk test was used to check normality. The Levene test was employed to check equality of variance. The Durbin-Watson test was employed to check for error uncorrelation.

\section{RESULTS}

The descriptive statistics for $\mathrm{Na}^{+}, \mathrm{K}^{+}, \mathrm{Cl}^{-}$and $\mathrm{HCO}_{3}{ }^{-}$ions, determined from 150 blood serum of English Thoroughbred horses, and its respective international reference values are shown in Table 2.

Table 2. Mean $(x)$, standard deviation (SD), reference value, confidence interval $(\mathrm{CI})$, and percentiles: $\mathrm{P}_{10}-\mathrm{P}_{90}$ and $\mathrm{P}_{25}-\mathrm{P}_{75}$ for different biochemical analytes $(n=150$ blood serum of English Thoroughbred horses)

\begin{tabular}{lccccc} 
& \multicolumn{1}{c}{$x \pm \mathrm{SD}$} & Reference $^{\mathrm{a}}$ & $\mathrm{CI}^{\mathrm{b}}$ & $\mathrm{P}_{10}-\mathrm{P}_{90}$ & $\mathrm{P}_{25}-\mathrm{P}_{75}$ \\
\hline Cations & & & & & \\
Sodium $(\mathrm{mM})$ & $137.57 \pm 1.59$ & $139 \pm 3.5$ & $137.31-137.82$ & $135.48-140.18$ & $136.48-138.44$ \\
Potassium $(\mathrm{mM})$ & $3.91 \pm 0.25$ & $3.51 \pm 0.57$ & $3.87-3.95$ & $3.61-4.25$ & $3.78-4.06$ \\
$\begin{array}{l}\text { Anions } \\
\text { Chlorine }(\mathrm{mM})\end{array}$ & $95.37 \pm 3.52$ & $104 \pm 2.6$ & $94.80-95.93$ & $90.86-100.45$ & $93.13-98.92$ \\
$\begin{array}{l}\text { Bicarbonate } \\
(\mathrm{mM})\end{array}$ & $24.13 \pm 2.29$ & $25 \pm 3.0$ & $23.76-24.50$ & $20.99-27.14$ & $21.97-26.76$ \\
\hline
\end{tabular}

${ }^{a}\left(\right.$ Kaneko et al., 2008) ${ }^{\mathrm{b}}$ confidence interval of $95 \%$. 
In general, the values for all biochemical analytes are consistent with the reference values reported internationally. Table 3 describes the comparison between groups. The $\mathrm{Na}^{+}$ion not showed significant changes 30min after exercise, and increase $60 \mathrm{~min}$ after. The $\mathrm{K}^{+}$ion showed increase 30min after exercise and decrease 60 min after. The $\mathrm{Cl}^{-}$ion showed a decrease $30 \mathrm{~min}$ after exercise, to recover gradually $60 \mathrm{~min}$ after. And the $\mathrm{HCO}_{3}{ }^{-}$ion showed increase 30min after exercise, decreasing slightly in the final stage.

Table 3. Comparison of different biochemical analytes in English Thoroughbred horses undergoing exercise, ( $n=50$ horses/group)

\begin{tabular}{lccc}
\hline & Rest & 30min after exercise & $\begin{array}{c}\text { 60min after } \\
\text { exercise }^{1}\end{array}$ \\
\hline Cations & $137.40 \pm 1.19^{\mathbf{a}, \mathbf{b}}$ & $137.20 \pm 1.81^{\mathbf{a}}$ & $138.10 \pm 1.60^{\mathbf{b}}$ \\
Sodium $(\mathrm{mM})$ & $3.71 \pm 0.13^{\mathbf{a}}$ & $4.10 \pm 0.27^{\mathbf{b}}$ & $3.93 \pm 0.13^{\mathbf{c}}$ \\
Potassium $(\mathrm{mM})$ & & & \\
Anions & $99.68 \pm 1.24^{\mathbf{a}}$ & $91.92 \pm 1.62^{\mathbf{b}}$ & $94.52 \pm 1.26^{\mathbf{c}}$ \\
Chlorine $(\mathrm{mM})$ & $21.48 \pm 0.67^{\mathbf{a}}$ & $26.88 \pm 0.57^{\mathbf{b}}$ & $24.03 \pm 0.53^{\mathbf{c}}$ \\
Bicarbonate $(\mathrm{mM})$ & &
\end{tabular}

${ }^{1}$ speed race of $12 \mathrm{~km} / \mathrm{h}$ for $30 \mathrm{~min}$ with no rest;significant differences were obtained between groups indicated with different letters; $(\mathrm{P}<0.05)$; all data are presented means $\pm \mathrm{SD}$.

\section{DISCUSSION}

The $\mathrm{Na}^{+}$ion was the most stable electrolyte, because it did not show significant changes in blood serum concentration, 30min after exercise (Figure 1). Mansley et al. (2017) reported that fine-tuning of $\mathrm{Na}^{+}$ion content occurs within the aldosterone-sensitive-distal-nephron (ASDN), whose activity increases during the exercise. They pointed out also that the aldosterone can promote $\mathrm{Na}^{+}$ion retention during exercise to offset changes in extracellular fluid volume, via the epithelial-sodium-channel (ENaC), in the kidney and the sweat glands. These assumptions could explain the stability of $\mathrm{Na}^{+}$ion in the blood serum.

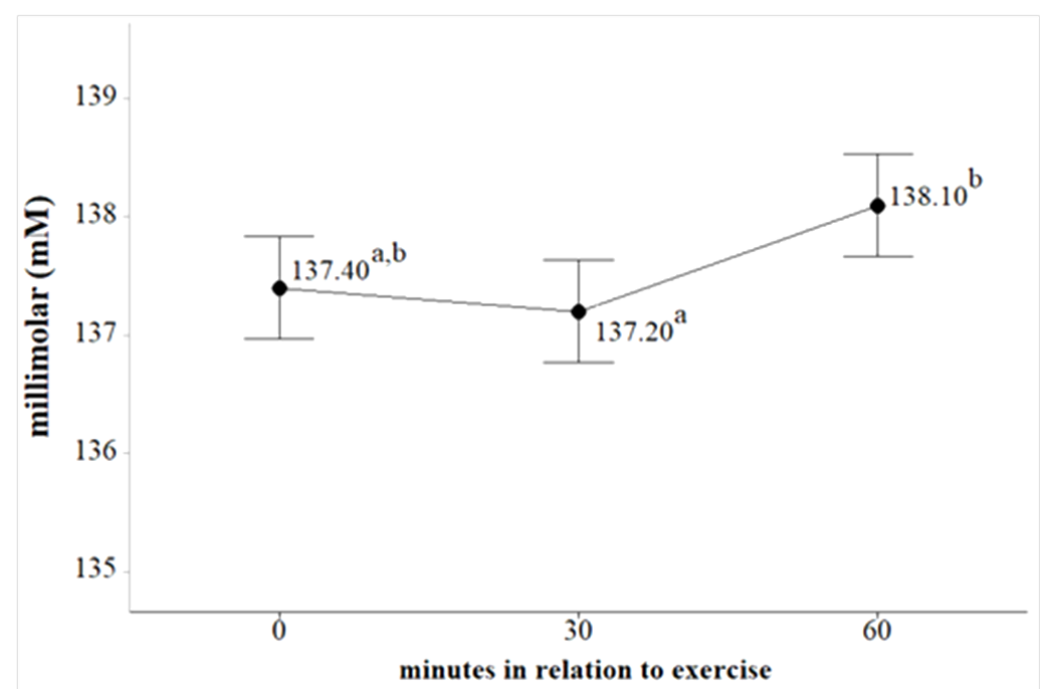

Figure 1. Comparison of sodium ion in English Thoroughbred horses undergoing exercise, $(n=50$ horses/group). ${ }^{\mathrm{a}, \mathrm{b}}$ significant differences were obtained between groups indicated with different letters $(\mathrm{P}<0.05)$; all data are presented means $\pm \mathrm{SD}$.

The aldosterone is a master regulator of renal $\mathrm{Na}^{+}$ion transport, but Hunter et al. (2014) reported that glucocorticoids are also influential, particularly cortisol elevated during exercise.
The hypothalamic-pituitary-adrenal (HPAA) axis can affect renal $\mathrm{Na}^{+}$ion homeostasis on multiple levels, systemically by increasing mineralocorticoid synthesis and locally by 
actions on both the mineralocorticoid and glucocorticoid receptors, both of which are expressed in the kidney. Therefore, cortisol can stimulate renal transport processes conventionally attributed to the reninangiotensin-aldosterone-system (RAAS), and its high concentration during exercise, could help maintain the stability of $\mathrm{Na}^{+}$ion in the blood serum.

The $\mathrm{K}^{+}$ion is the most abundant intracellular cation, and its concentration in the extracellular space is low due to the action of the $\mathrm{Na}^{+} / \mathrm{K}^{+}$-
ATPase which pumps three $\mathrm{Na}^{+}$ion out of the cell in exchange for two $\mathrm{K}^{+}$ion(Rodan, 2016). Thus, $98 \%$ of total body $\mathrm{K}^{+}$ion is found in intracellular stores, chiefly in muscle (Terker et al., 2015). Mora et al. (2015) reported that dehydrating exercise reduce muscle water $\left(\mathbf{H}_{2} \mathbf{O}_{\text {muscle }}\right.$ ) seemly to restore plasma volume (PV). In response to the $\mathrm{H}_{2} \mathrm{O}_{\text {muscle }}$ reductions the $\mathrm{K}^{+}$ion will exit the muscle cells and enter the bloodstream, increasing your concentration (Figure 2) (Rodan, 2016).

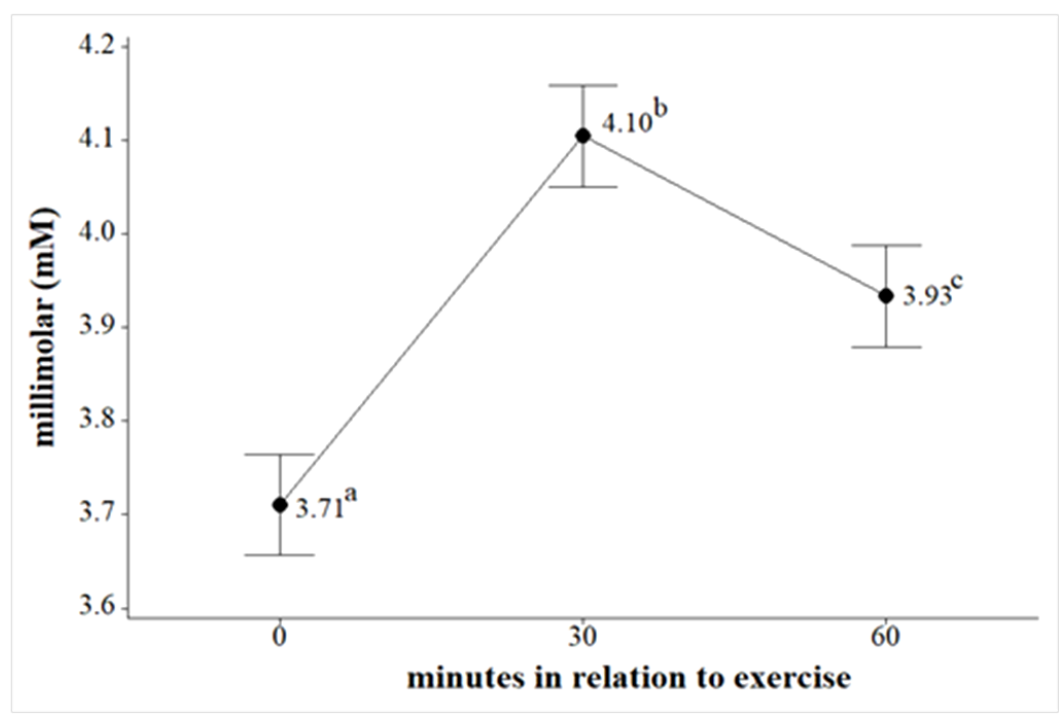

Figure 2. Comparison of potassium ion in English Thoroughbred horses undergoing exercise, $(n=50$ horses/group). ${ }^{\mathrm{a}, \mathrm{b}}$ significant differences were obtained between groups indicated with different letters $(\mathrm{P}<0.05)$; all data are presented means $\pm \mathrm{SD}$.

The amount of $\mathrm{K}^{+}$ion entering the bloodstream is dependent on the intensity and duration of the workload (Mora et al., 2015). This is a transient effect, as $\mathrm{K}^{+}$ion levels in the blood will peak and then begin to decline as it recovers in organism (Terker et al., 2015), which can be attributed to losses in the sweat (Potts et al., 2015).

The nature of equine sweat is alkaline, since their sweat glands are primarily secretory of $\mathrm{Cl}^{-}$ion, sulphates and phosphates (Tomich et al., 2018). Therefore, the equine sweat is hypertonic with respect to blood serum (Potts et al., 2015). During exercise the sweating of horse is accompanied by a significant loss of $\mathrm{Cl}^{-}$ion (Figure 3), with a consequent reduction in blood serum (Demirtaş et al., 2015).

Arias et al. (2014) quantified the losses of $\mathrm{Cl}^{-}$ion in horse sweat, and when comparing their concentration: $110 \pm 12.3 \mathrm{~m}$-equiv/L in blood serum with $280.6 \pm 18.5 \mathrm{~m}$-equiv/L in sweat, reported that the loss of this electrolyte for every $\mathrm{L}$ of sweat is elevated. The amount of $\mathrm{Cl}^{-}$ion entering the bloodstream is dependent on the intensity and duration of the workload and then begin to decline $60 \mathrm{~min}$ after exercise as it recovers in organism (Demirtaş et al., 2015). 


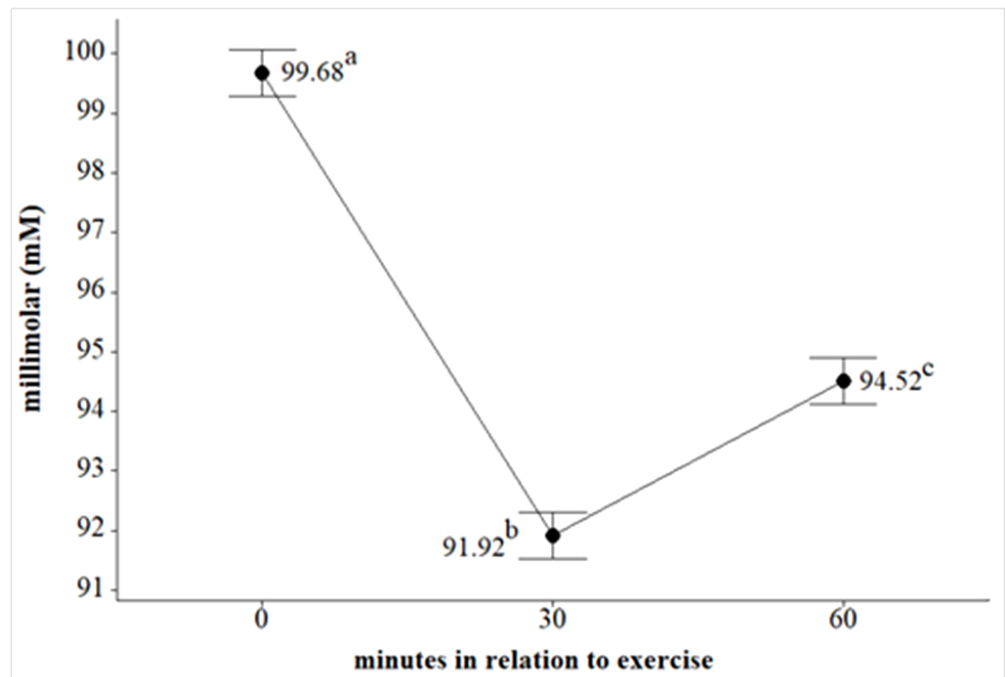

Figure 3. Comparison of chlorine ion in English Thoroughbred horses undergoing exercise, $(n=50$ horses/group). ${ }^{\text {a, b }}$ significant differences were obtained between groups indicated with different letters $(\mathrm{P}<0.05)$; all data are presented means $\pm \mathrm{SD}$.

The loss of high amount of $\mathrm{Cl}^{-}$ion causes deficit in blood serum (hypochloremia). Hypochloremia increases strong-ion-difference (SID) value. In these cases, $\mathrm{Cl}^{-}$ion depletion also plays a crucial role in maintaining metabolic alkalosis (Hamilton et al., 2017). The lower $\mathrm{Cl}^{-}$ion concentration in the tubular lumen also impairs activity of luminal $\left(\mathrm{Cl}^{-}-\mathbf{H C O}_{3}{ }^{-}\right)$exchanger in type $\mathrm{B}$ intercalated cell and leads to reduced excretion of $\mathrm{HCO}_{3}{ }^{-}$ion. Therefore, the body presents high levels of $\mathrm{HCO}_{3}^{-}$ion, 30min after exercise as anion compensation (Figure 4).

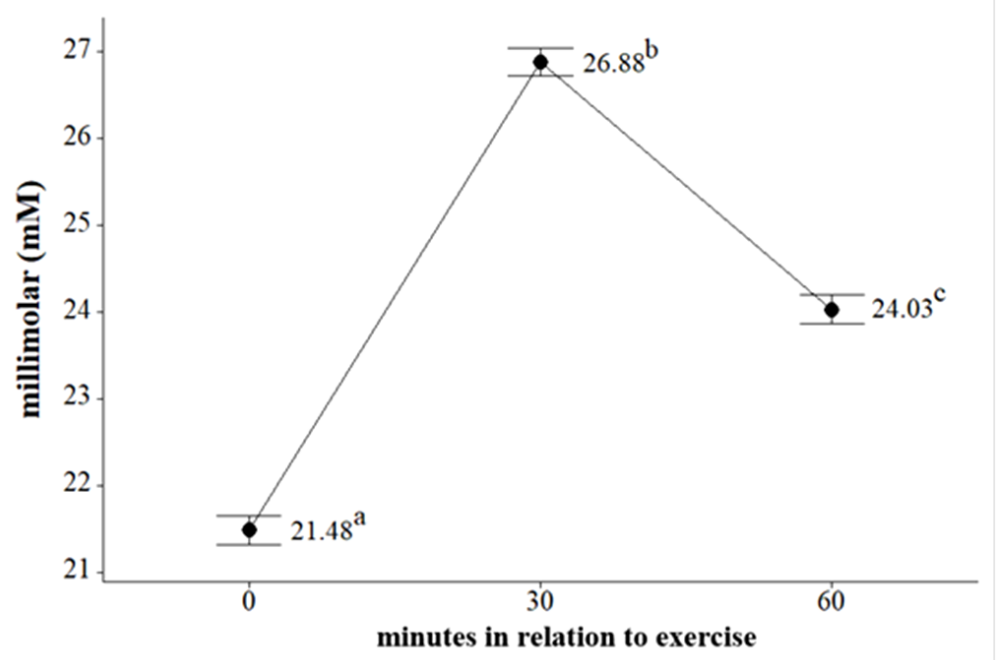

Figure 4. Comparison of bicarbonate ion in English Thoroughbred horses undergoing exercise, $(n=50$ horses/group). ${ }^{\mathrm{a}, \mathrm{b}}$ significant differences were obtained between groups indicated with different letters $(\mathrm{P}<0.05)$; all data are presented means $\pm \mathrm{SD}$.

To maintain acid-base balance of blood, there are many different buffer systems in the body, but the key one for compensate most acid-base disorders is the $\mathrm{HCO}_{3}{ }^{-}$ion (Kataoka, 2017). The $\mathrm{Cl}^{-}$ion is reabsorbed and excreted in inverse proportion to $\mathrm{HCO}_{3}{ }^{-}$ion $(\mathrm{r}=-0.87 ; \mathrm{P}<0.05)$, equation $\mathrm{HCO}_{3}{ }^{-}$ion $=78.86-0.5739 \mathrm{Cl}^{-}$ion (Figure 5).Conversely, hyperchloremia would lead to metabolic acidosis and renal elimination of $\mathrm{HCO}_{3}{ }^{-}$ion (Kataoka, 2017). 


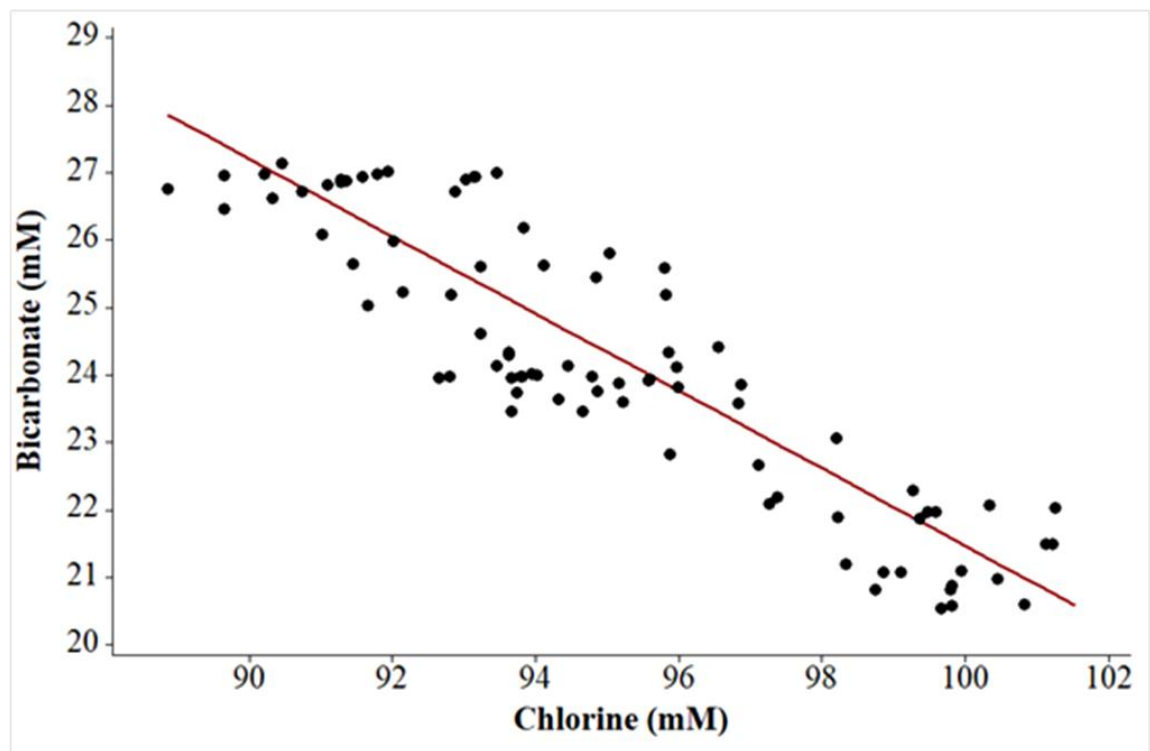

Figure 5. Relationship between bicarbonate and chlorine. Bicarbonate $(\bullet)$; predicted response $(-)$.

\section{CONCLUSIONS}

The exercise tests are useful for the determination of acid-base balance and osmotic balance, and their main role is to evaluate the athletic ability of horses. The calculated confidence intervals could be used at herd level to detect alert situations when at least $5 \%$ of the sampled cows would fall outside of the calculated reference interval for a given parameter. Considering that chloride ion excretion and metabolic adjustments of potassium ion and bicarbonate ion are superior to water loss, compared to the normal osmolarity of blood serum. The results found can be used to structure an adequate replacement program of electrolytes lost in sweat.

\section{ACKNOWLEDGMENTS}

This project was supported by the National Council of Science and Technology-México (CONACyT-México). The authors wish to thank the social serviceJudith Alejandre-López.

\section{REFERENCES}

ARIAS, G.M.P.; MEJÍA, S.G.; SÁENZ, R.O.A. Concentration of sweat electrolytes in Colombian Creole Horses. Rev. CES Med. Vet. Zootec., v.9, p.43-51, 2014.

DEMIRTAŞ, B.; YARAMIŞ, Ç.P.; ATMACA, M. Exercise induced physiological fatigue in horses. Turk. Klinikleri. J. Vet. Sci., v.6, p.60-66, 2015.

DOHERTY, O.; MCGREEVY, P.D.; PEARSON, G. The importance of learning theory and equitation science to the veterinarian. Appl. Anim. Behav. Sci., v.190, p.111-122, 2017.

HAMILTON, P.K. et al. Understanding acidbase disorders. Ulster Med. J., v.86, p.1-6, 2017.

HUNTER, R.W.; IVY, J.R.; BAILEY, M.A. Glucocorticoids and renal $\mathrm{Na}^{+}$transport: implications for hypertension and salt sensitivity. J. Physiol., v.592, p.1731-1744, 2014.

KATAOKA, H. The "chloride theory", a unifying hypothesis for renal handling and body fluid distribution in heart failure pathophysiology. Med. Hypotheses, v.104, p.170-173, 2017. 
KANEKO, J.J.; HARVEY, W.J.; BRUSS, L.M. (Eds.). Blood analyte reference values in large animals. California, Estados Unidos: Academic Press, 2008. p.882-888. (CLINICAL biochemistry of domestic animals).

MANSLEY, M.K. et al. Aldosterone-induced $\mathrm{Na}^{+}$absorption is regulated by protein acetylation in a cellular model of the cortical collecting duct. FASEB. J., v.31, p.857, 2017.

MARTINS, J.A. et al. Blood and urinary variables in horses supplemented with electrolytes. Comp. Exerc. Physiol., v.10, p.123130, 2014.

MORA, R.R. et al. Skeletal muscle water and electrolytes following prolonged dehydrating exercise. Scand. J. Med. Sci. Sports, v.25, p.e274-e282, 2015.

NAGY, A.; DYSON, S.J.; MURRAY, J.K. Veterinary problems of endurance horses in England and Wales. Prev. Vet. Med., v.140, p.45-52, 2017.

OLFERT, D.E.; CROSS, M.B.; MCWILLIAM, A.A. (Eds.). Guide to the care and use of experimental animals. Ottawa, Ontario: Canadian Council on Animal Care, 1993. p.6569. (FARM animal facilities and environment/Cattle).

POTTS, S. et al. Sweat osmolarity shows intraanimal regional variation in the horse. Vet. Dermatol., v.26, p.e74-e84, 2015.
RANDLE, H.; WARAN, N. Breaking down barriers and dispelling myths: the need for a scientific approach to Equitation. Appl. Anim. Behav. Sci., v.190, p.1-4, 2017.

RODAN, A.R. Potassium: friend or foe? Pediatr. Nephrol., v.3, p.1109-1121, 2016.

SANIN, L.Y.; CABRERA, Z.A.M.; MORALES, T.A.M. Adaptive responses to thermal stress in mammals. Rev. Med. Vet., v.1, p.121-135, 2015.

SOETAN, K.O.; OLAIYA, C.O.; OYEWOLE, O.E. The importance of mineral elements for humans, domestic animals and plants. A review. Afr. J. Food. Sci., v.4, p.200-222, 2010.

SPSS Statistics user's guide. Version 22.0. Armonk: IBM Corp., 2013.

TERKER, A.S. et al. Potassium modulates electrolyte balance and blood pressure through effects on distal cell voltage and chloride. Cell. Metabol., v.21, p.39-50, 2015.

TOMICH, L.M.; PIEPER, J.B.; STERN, A.W. Comparing dermoscopy and histological examination of normal equine skin. Vet. Dermatol., v.29, p.170-176, 2018.

WILBERGER, M.S. et al. Prevalence of exertional rhabdomyolysis in endurance horses in the Pacific Northwestern United States. Equine. Vet. J., v.47, p.165-170, 2015. 